\title{
The Future of Office Workplaces with an Emphasis on Ergonomics
}

\author{
Eleonóra Bigošová ${ }^{1}$, Blanka Horváthová ${ }^{1}$, L'uboslav Dulina ${ }^{1}$ \\ ${ }_{1}$ University of Žilina, Faculty of Mechanical Engineering, Department of Industrial \\ Engineering \\ Univerzitná 1, 01026 Žilina, Slovakia \\ eleonora.bigosova@fstroj.uniza.sk \\ blanka.horvathova@fstroj.uniza.sk \\ luboslav.dulina@fstroj.uniza.sk
}

\begin{abstract}
Annotation: A healthy and satisfied employee is the basis of every production process and a prerequisite for a prosperous business. As a result of natural, technological progress, the structure of professions is changing, and their performance is closely linked to the use of computers and new technologies. According to a survey of the most frequently registered professions in Slovakia, up to $60 \%$ of professions are concentrated in offices; the primary working position is sitting. Epidemiological studies point to an increasing number of diseases of the musculoskeletal system caused by the accumulation of static load during long-term sedentary work tasks. A new task of ergonomics is, therefore, to evaluate, improve and design office workplaces to ensure the physical and psychosocial needs of workers and eliminate factors that increase the influence of static load on the human body.
\end{abstract}

\section{Introduction}

Productive workers are considered a competitive resource. How employees work together, and at the same time, their workspace forms the quality of work. Stress and workload contribute significantly to work-related health problems, and occupational diseases may occur. Occupational diseases are called diseases that arise in a causal relationship with the work performed as a result of adverse effects of chemical, physical, biological, and other risk factors in the working environment. In 2018, 308 cases of occupational diseases were reported in Slovakia (121 women and 187 men). Compared to 2017, the number of these diseases decreased by 46 cases. In the long term, we see their decreasing trend. As in previous years, professional diseases affecting the musculoskeletal system, blood vessels, and nervous system of workers exposed to long-term unilateral load were the main contributors to the total number of occupational diseases (Figure 1) [1]. 


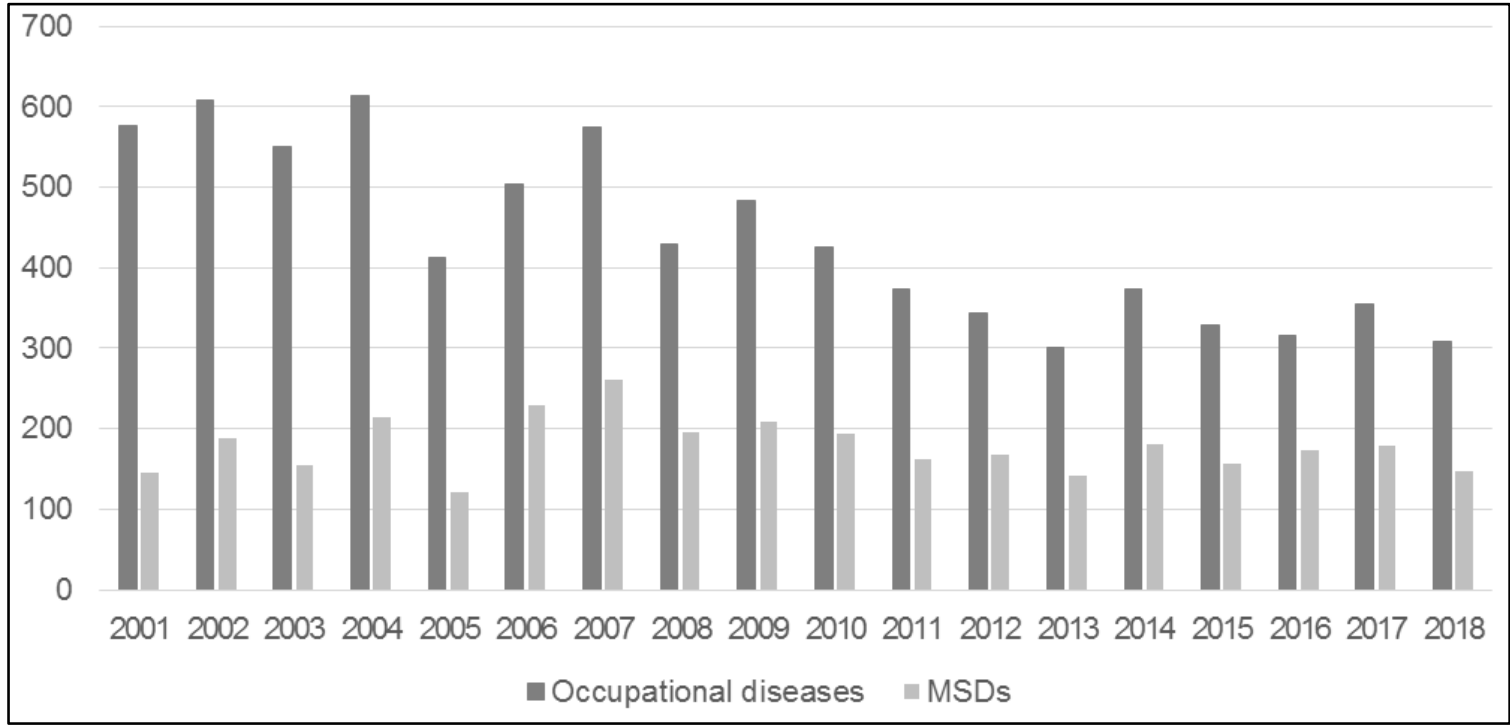

Figure 1 - Evolution of the number of occupational diseases and diseases from longterm unilateral overload [1]

Due to the natural human need to facilitate or completely replace manual work by machines, human activity is focused on the development, construction, and management of these machines. These activities are now closely tied to the use of computers as a tool for developing new technologies and controlling processes. The primary working position in these professions is sitting [2]. According to the realized survey, up to $60 \%$ of the most frequently registered professions in Slovakia are carried out in a sitting position (Figure 2).

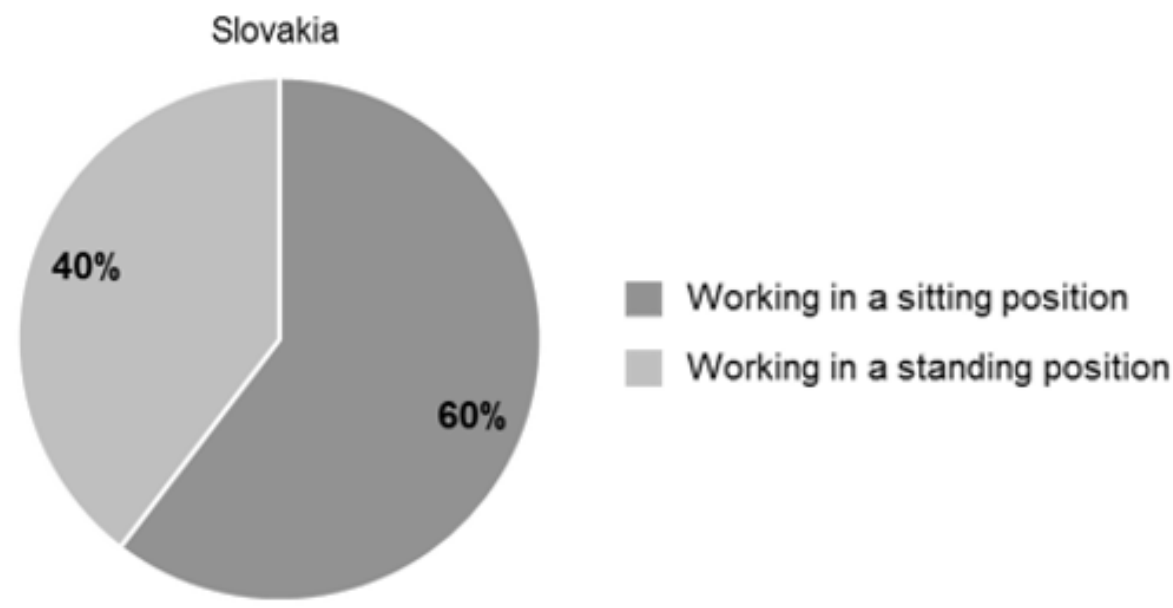

Figure 2 - Graphical representation of the percentage of sedentary professions among the professions in Slovakia [author]

\section{Factors affecting human in a sedentary occupation}

When performing work whose primary working position is sitting, a low-level static load affects the human body. The consequences of this type of stress are manifested after long-term accumulation in the body. Recent epidemiological studies point to an increased incidence of musculoskeletal disorders caused by sedentary work [2]. The most commonly affected area is the area of the cervical 
and lumbar spine; $80 \%$ of all adults suffer from back pain during their working life [3]. The load on the lumbar spine is significant in the sitting position compared to standing [4]. When standing upright, the spine forms an active pathway for even load distribution. During a sitting, angle of the natural lordotic curvature of the spine is reduced. In this case, intervertebral discs are compressed, and there is a higher risk of their damage. Generally, the following factors affect the static load:

- Working position;

- the duration of the task;

- the force applied;

- frequency of movements;

- workplace layout;

- dimensional parameters of the workplace;

- anatomical properties.

It is also necessary to focus on the sensory load, which has a significant impact on employee performance, especially when using a computer or other display units throughout their working hours. Sensory stress results from the requirements for peripheral sensory organs and their corresponding structures of the central nervous system [5]. Sensory load refers to the burden of hearing, sight, and other senses (vestibular apparatus and tactile sensations) [6].

\section{$3 \quad$ Ergonomic workplace}

The ergonomically designed workplace can significantly reduce the sickness rate of employees caused by poor physical or psychosocial work environments. Ergonomic workplaces are designed to meet the functional needs of workers. They are flexible and thus increase well-being and productivity. The ergonomic workplace is designed to support healthy and productive workers. Essential aspects to consider when creating an ergonomic workspace are [7]:

- Different types of ergonomics - the ergonomic design offers a solution for a variety of factors that affect well-being and productivity.

- Cognitive factors - stress, human interactions.

- Physical factors - sitting or standing positions, workspace layout, and environmental factors (light, sound, etc.)

- Ergonomic furniture - Investing in ergonomic furniture creates the best possible working conditions. Furniture designed to adapt to the individual needs of each worker brings increased motivation, higher productivity, and lower levels of accidents and incapacity for work.

- Sound ergonomics and acoustics - Workspace acoustics is an important aspect of ergonomic design. Noise affects concentration, 
communication, and decision making. Furniture can be a significant source of unwanted noise.

- Workspace lighting - Light plays an important role in productivity, helping us stay awake during the working day. Natural light is also suitable for our well-being at work because it affects the natural circadian rhythms of our body that control the release of stress hormones.

\subsection{Open Office versus Classic Office}

Employers and workers benefit from an ergonomically designed workspace. By investing in ergonomics, they let workers know that their work is valued. Considering ergonomic solutions designed to meet the individual needs of workers leads to increased motivation, higher productivity, lower accidents, and incapacity for work. The key is to create an environment that promotes cooperation. Office space can be divided into two primary groups - personal closed offices (classic offices) and open office offices.

\section{Classic offices}

A classic office is a workspace for one, up to two employees. These spaces offer more privacy, a quieter environment, and the possibility of individual workspace layout. They are mainly used by smaller companies or companies that require employees to concentrate, creativity, work, or communicate in a quiet environment. The disadvantage of this solution is mainly lower efficiency of space utilization; therefore, they are used much less than Open Space offices [8].

\section{Open Office}

Large companies often place their teams in large open offices known as Open Space or Open Office [8]. Open office offices have been used frequently since the 1980s because they require lower space costs and are also expected to increase employee collaboration. However, what is untrue from the survey; people in open offices talk more together, but not about work-related things. The many people working in such offices experience many drawbacks and discomfort, especially in the absence of privacy. Workers in Open Space offices lose up to 90 minutes of working time per day due to distractions, and this is one of the reasons why Open Office Offices are increasingly criticised not only by the employees themselves but also by scientists who examine its impact on human performance and health.

According to a survey by Ipsos and Steelcase, involving more than 10,000 employees in 14 countries, up to $85 \%$ of employees are dissatisfied with the quality of their work environment and cannot concentrate. Open Space offices have limited ability to think creatively and constructively. In the survey, up to $95 \%$ of workers surveyed declared that private space for work was significant for them and as many as 31\% of them left home for work to complete their tasks at all [8]. 
According to the Human Spaces study, which examined the working environment of 3600 employees from 8 EMEA countries, $55 \%$ of people have no greenery at work, $42 \%$ of workers lack daylight, and $22 \%$ do not have the necessary silence to concentrate on work. According to the Forbes survey, more than a third of employees ( $36 \%$ ) would give up part of their income to feel happier at work and to have a more comfortable working environment [8]. For these reasons, Open Space architects are now enriching the space with a variety of rest areas where workers can relax.

\subsection{The future of ergonomic workplaces}

As technology continues to shape the way people work, future generations of workers need flexible solutions to meet their individual needs. Companies that invest in ergonomic solutions perceive the benefits of improving employee satisfaction and engagement and reduced incapacity for work. Large open offices, as well as closed offices, are increasingly adapting to the specific requirements of companies. This adaptation can also be seen in the historical development of the design of the office space itself and its functional elements (Figure 3). It is clear that the nature of the workplace significantly affects work efficiency, psychological well-being, and employee satisfaction [8].

Investing in ergonomic solutions is an investment for the future as it ensures the continued success of individuals and businesses. In the future, ergonomic workspaces are likely to attract talented workers who have a choice between employers and want to work in an environment designed for their needs [8].

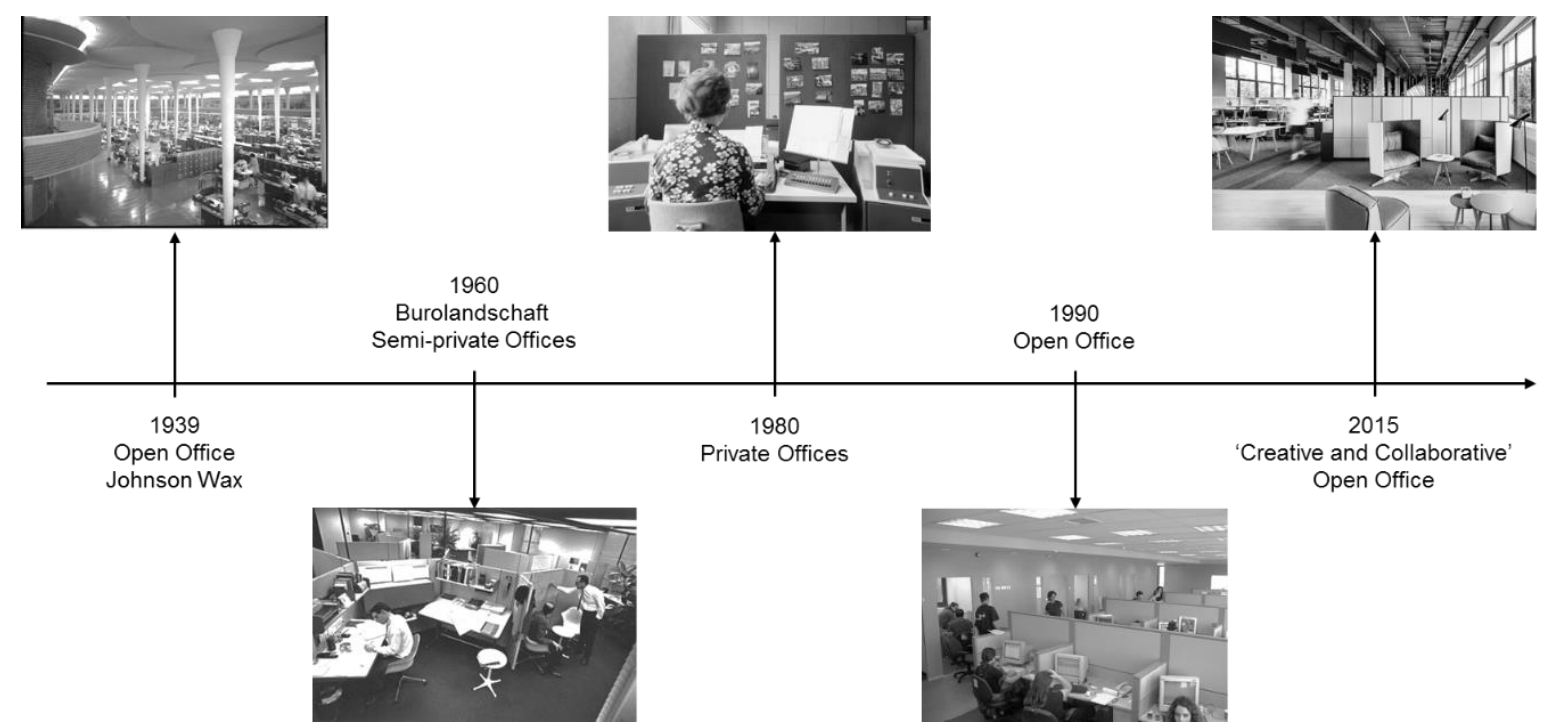

Figure 3 - Development of office space design [author, 9, 10, 11]

The ergonomic workspace should not only meet the basic functionality requirements concerning the work performed but should also be adaptive to each worker. When designing an ergonomic workplace, it is necessary to consider the individual anatomical, biomechanical, and psychological needs of 
man. The framework requirements and prerequisites for creating an ergonomic office workspace are summarised in Figure 4.

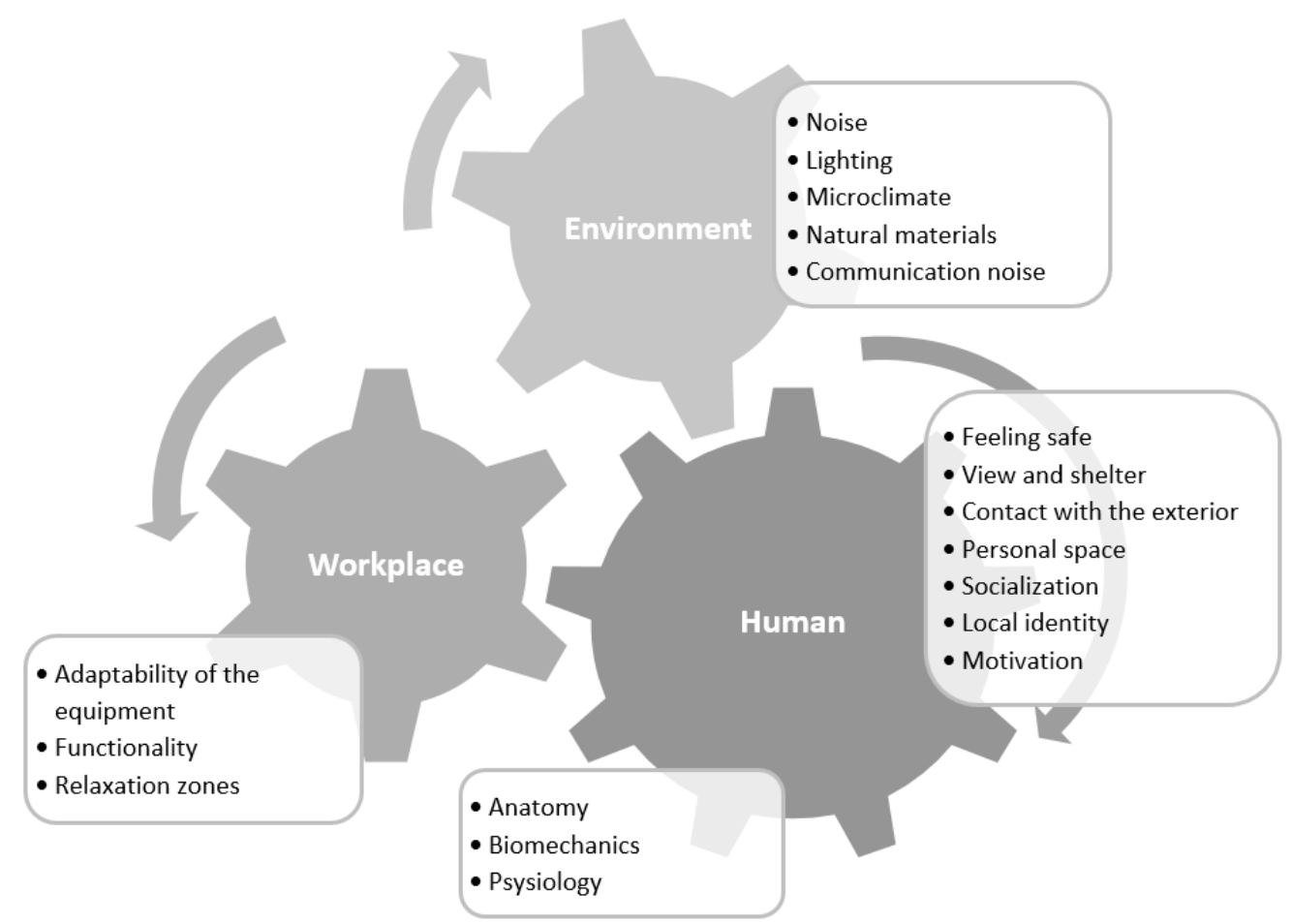

Figure 4 - Requirements for ergonomic office workspace [author, 12]

Benefits of an ergonomic workspace:

- Increased performance and motivation.

- Lower levels of sick leave.

- Increased efficiency.

- Better long-term health and satisfaction.

- Reduce the risk of injury.

- A flexible solution for the future.

- Increased employee engagement.

Workspace layout shapes productivity. It is essential to reflect on the needs of workers and take them into account in the workspace. Ergonomic space is one that meets the functional requirements of workers. It improves comfort at work as ergonomic solutions can be adapted to the individual needs of individual workers. Solutions that improve well-being and satisfaction ensure that workers remain within businesses. Another important factor to focus on is movement. Designing a workspace that promotes movement helps employees feel comfortable and productive. Activity-based workstations allow workers from different departments to collaborate on different tasks. Instead of working all 
day at the desk, workers can move and meet in specific areas for a specific task. This type of movement beneficial for communication and cooperation has benefits for the physical health and well-being of workers. [8, 13]

\section{Conclusion}

The modern human population ceases to move during both working and nonworking life. The consequences of such a lifestyle have been known for decades - obesity, cardiovascular disease, posture disorders, and pervasive stress that affects the health of the population like grey eminence. Due to the natural development of the society towards the implementation of technologies simplifying and accelerating the work process, the number of jobs with the primary sitting working position is increasing; thus the static load of the organism also increased.

The subject of the dissertation, as well as the further direction of research in the field of office workplaces, will be to develop an intelligent adaptive dynamic workplace that would autonomously adapt to its user without its own intervention and ensure active change of working position based on predefined time intervals.

It is important, with a view to the future and technological progress, to think about employee satisfaction, reducing their psychological burden, and increasing their creativity and performance. In the future, it will be necessary for employees to create separate working environments that meet ergonomic principles while ensuring seamless communication between them. It is anticipated that such solutions will lead to higher performance and efficiency in carrying out work activities as well as collaboration on joint projects. Investing in ergonomic solutions is a sensible investment that ensures continued business success. Ergonomic solutions create the best working conditions. As ergonomic workspaces are and will be, designed to improve worker well-being, businesses ultimately benefit from lower costs of incapacity and absence.

\section{Acknowledgements}

This article was created with the support of the project: KEGA 022ŽU-4/2018

\section{References}

[1] Legáth L'. Choroby z povolania alebo ohrozenia chorobou z povolania 2018. [online] Národné centrum zdravotníckych informácií. [online] 2019, [cit. 8. 8. 2019], http://data.nczisk.sk/statisticke vystupy/choroby povolania/Choroby z povo lania 2018 Sprava k publikovanym vystupom.pdf

[2] Hatiar K., Bršiak, V. Priemyselná revolúcia a prevencia t’ažkostí a chorôb podporno-pohybového systému súvisiacich s prácou. In: Životné podmienky a zdravie: zborník vedeckých prác. Univerzita Komenského v Bratislave, 2018. s. 195-211. ISBN 978-80-223-4523-1 
[3] Berlin C., Adams, C. Production Ergonomics: Designing Work Systems to Support Optimal Human Performance. Ubility Press, London, 2017. ISBN 978-1-911529-13-2.

[4] Andersson, B. J. et al. The sitting posture: an electromyographic and discometric study. The Orthopedic clinics of North America, 1975, Vol. 6., No. 1, p. 105-120.

[5] Slamková E., Dulina L'., Tabaková, M. Ergonómia v priemysle. GEORG, Žilina, 2010. ISBN 978-80-89401-09-3.

[6] Štefánik M. et al. Labour Market in Slovakia 2019+. [online] 2018, [cit. 8. 8. 2019], http://www.ekonom.sav.sk/uploads/journals/390 labour market in slovakia 2019.pdf

[7] Ergonomické pracovné priestory. [online], [cit. 8. 8. 2019], https://www.kinnarps.sk/vedomosti/ergonomics/ergonomic-workspaces/

[8] Klasické vs. Open Space kancelárie. [online], [cit. 8. 8. 2019], https://www.kancelarie.sk/novinky/tlacit/klasicke-vs-open-space-kancelarie

[9] 1960's: The dawn of the age of the cubicle. [online], [cit. 13. 8. 2019] http://www.cofcogroup.com/1960s-the-dawn-of-the-age-of-the-cubicle/

[10] Working in cubicles or an open office? [online], [cit. 13. 8. 2019] http://prevenblog.com/en/working-cubicles-open-office/

[11] Evolution of the workplace - from individual offices to hubs. [online], [cit. 13. 8. 2019] https://www.senaatti.fi/en/workenvironments/inspiration/article/evolution-workplace-individual-offices-hubs/

[12] Kotradyová, V. 11 vlastností podporného prostredia pre člověka. In: Ergonómia 2017 - berieme ergonómiu vážne : zborník z medzinárodnej vedeckej konferencie. Slovenská ergonomická spoločnost', Žilina, 2017. ISBN 978-80-970974-3-1.

[13] Martinkovič M., Mičieta B., Biňasová V. Human-Robot Cooperation. In: Industrial Engineering - Invention for enterprise: InvEnt 2019. ISBN 978-8366249-17-2. 